\title{
Plain English Movement and Penman's Criticism to Strengthening the Movement*
}

\author{
Andi Syafrani ${ }^{1}$ \\ UIN Syarif Hidayatullah Jakarta \\ DOI: $10.15408 /$ sjsbs.v5i1.7907
}

\begin{abstract}
Abstrak:
The plain English movement has been commencing for many decades. Recently, the movement has penetrated beyond English-speaking countries. Plain English involves the use of straightforward and clear language. Additionally, it uses modern and standard English. Penman's criticisms range from the trivial aspect to the deeply critical concerning the communication approach in legal language. She has written essays reviling plain English in some journals such as: 'Plain English: wrong solution to an important problem'.

Keywords: Plain English, Movement, Criticism.

Abstrak:

Gerakan Bahasa Inggris telah dimulai selama beberapa dekade. Baru-baru ini, gerakan ini telah memasuki beberapa negara pengguna bahasa Inggris. Bahasa Inggris melibatkan penggunaan bahasa yang lugas dan jelas. Selain itu, menggunakan bahasa Inggris modern dan standar. Kritik Penman dalam hal ini berkisar dari aspek sederhana hingga kritis mengenai pendekatan komunikasi dalam bahasa hukum. Dia telah menulis esai yang mengkritik penggunaan bahasa Inggris Hukum yang sederhana dalam beberapa jurnal seperti: 'Plain English: solusi salah untuk masalah penting'.

Kata kunci: Bahasa Inggris Biasa, Gerakan, Kritik.
\end{abstract}

* Received: March 20, 2018, Revised: April 27, 2018, Accepted: Mei 25, 2018.

${ }^{1}$ Andi Syafrani is a lecturer at Department of Law, Faculty of Sharia and Law, UIN Syarif Hidayatullah Jakarta. E-mail: andi.syafrani@uinjkt.ac.id. 
The plain English ${ }^{2}$ movement has been commencing for about five decades. $^{3}$ Recently, the movement has penetrated beyond English-speaking countries to places like Japan. ${ }^{4}$ Calls for clear, simple and precise laws have been echoed by members of public to lawmakers around the globe: the calls for plain language. However, some criticisms still arise. ${ }^{5}$ And one of the harshest criticisms came from Robyn Penman, a communication expert from Communication Research Institute of Australia in Canberra. Her notion has created a lot of debate. ${ }^{6}$ This essay will scrutinize her criticism.

Penman's criticisms range from the trivial aspect to the deeply critical concerning the communication approach in legal language. She has written essays reviling plain English in some journals such as: 'Plain English: wrong solution to an important problem' ${ }^{7}$ As can be seen from the title, Penman directly identifies plain English as the wrong way to increase comprehensibility and readability in legal language. Accordingly, in that article, she questions the

${ }^{2}$ The use of plain English will be interchangeable in this essay with plain language. The later has general meaning embracing languages other than English. For that reason, Asprey used plain language in her book. See, Michele M Asprey, Plain Language for Lawyers, (NSW: the Federation Press, $2^{\text {nd }}$ edition, 1999), p. 11.

${ }^{3}$ However, the first stepping stone of the plain English movement is not the same. For example, Joseph Kimble signed the movement's birthday with several events relating to costumer movement in 1970's such as when Nationwide Mutual Insurance Company simplified its insurance policies in 1974 and when President Carter issued an executive order directing that federal regulations must be as simple and clear as possible in 1978. However, he conceded that intellectual ground of plain English has been developed since David Mellinkoff published his book 'The Language of The Law' in 1963. See J. Kimble, Plain English: A Charter for Clear Writing, 9 Thomas M. Cooley Law Review 1, (1992), pp. 2-8. Peter Butt and Richard Castle started the history of the movement since 1960s. It was in the United Kingdom when Anthony Parker published his edited book 'Modern Conveyancing Precedent' in 1964. See P. Butt and R. Castle, Modern Legal Drafting A Guide To Using Clearer Language, (Cambridge University Press, Victoria, 2001), pp. 58-60. Both Kimble and Butt and Castle agreed that the plain English movement has been started in 1960s but with different moment. Kimble deemed Mellinkoff as the founding father of the movement but Butt and Castle placed Parker as the modern establisher of it. However, they are in one point in associating the movement with consumers' movement. Differently, Penman pointed out the formation of committee on Public Doublespeak in the USA in 1971 as the first establishment of the movement. See R. Penman, Plain English; Wrong Solution to an Important Problem, 19 Australia Journal of Communication 3 (1992), p.1, and Unspeakable Acts and Other Deeds: A Critique of Plain Legal Language, 7/2 Information Design Journal 12 (1993), p.121. The latest writing by Beth Mazur credited Stuart Chase as an original plain English proponent. She followed Redish (1985) and Schriver (1997) putting Chase's book 'The power of words' (1953) as a stepping stone of the movement. See B. Mazur, Revisiting Plain Language, 47 Technical Communication, the Journal of the Society for Technical Communication 2 (May 2000).

${ }^{4}$ Penman supra note 1 (1992), pp.1-2 and (1993) p.121.

${ }^{5}$ Kimble likened the critics to myths. See Joseph Kimble, Writing for Dollars, Writing to Please, 6 The Subscribe Journal of Legal Writing 1 (1996-1997), and The Great Myth That Plain Language Is Not Precise, 7 The Subscribe Journal of Legal Writing 109 (1998-2000).

'One of the clearest answers responding to Penman's criticism was made by J. Kimble, Answering the Critics of Plain language, 5 Scribes Journal Legal Writing 51 (1994-1995).

${ }^{7}$ R. Penman (1992). 
meaning of plain English and its scope, rejects evidence provided by the movement and makes counter evidence. Lastly she discusses the concept of communication following the constructionist model and the postmodernism tenet to discard the 'universality' of plain English. In another article, 'Unspeakable Acts and other deeds: a critique of plain legal language', ${ }^{8}$ she narrows plain English to text-based approach writing, rather than reader-based approach. Here, I will explore her arguments and critically examine them one by one.

\section{Plain English definition}

Penman's critique starts from a superficial debate on what plain English means. Following Charrow's position (What is Plain English Anyway?) in 1979, Penman questions plain English definition. She points that its definition is vague and furthermore its scope is not focused, rather changes from one particular field to another. ${ }^{9}$

It is clear to some extent that Penman ignores many 'definitions' of plain English made by its exponents. ${ }^{10}$ Her ignorance might come from her misperception. She uses capital ' $\mathrm{P}$ ' in writing plain English as a term. She might think of plain English as a new English style or another kind of English. For her plain English is like an alien or at least another technical term that needs a common definition. In fact, it is neither a variety of English nor a word of art. It is ordinary English but it is written in a clear and simple style. ${ }^{11}$

Plain English involves the use of straightforward and clear language. Additionally, it uses modern and standard English. ${ }^{12}$ Furthermore, it rejects convoluted, prolix and repetitive language. ${ }^{13}$ However, it is not a simplistic language or a kind of baby-talk. Simple does not have to be simplistic. It means precise, clear and straightforward. ${ }^{14}$

\footnotetext{
${ }^{8}$ R. Penman (1993).

9Penman (1992), p.3.
}

${ }^{10} \mathrm{I}$ put an apostrophe in definition's term because actually the plain English is not a technical term or a word of art. Therefore, it does not need a definition. It is simply a phrase used for referring to a kind of movement in particularly legal writing. However, Mowat collected a variety of plain English definition. There are 10 definitions of plain English in her collection. See, C. Mowat, A Plain Language Handbook for Legal Writers, (Toronto, Carswell, 1999), pp. 3-12. What I understand from definitions of plain English collected by Mowat is only descriptive information about what plain English intends to or what its objectives are.

${ }^{11}$ M. M Asprey, Plain Language for Lawyers, (NSW: the Federation Press, $2^{\text {nd }}$ edition, 1999), p.11.

${ }^{12} \mathrm{P}$. Butts, The Assumptions Behind Plain Legal Language, paper presented in the Fourth Biennial Conference of PLAIN Language Association International, Canada: September, 27, 2002, p. 2.

${ }^{13}$ Law Reform Commission of Victoria, Plain English and the Law, report No. 9 (1987), p.39.

${ }^{14}$ Asprey (1999), p.11. 
The differences, or according to Penman the vagueness, in defining plain English might come from the word "plain" itself. But the word "plain" is not drab. ${ }^{15}$ It means "clear, easy to understand, simple, honest and direct". ${ }^{16}$ However, the criteria of plainness are not standard. ${ }^{17}$ Every drafter has his or her own guideline in determining how to create plainness in legal documents. And the guidelines are not ruling which the proponents must stick to. ${ }^{18}$ Therefore, plain English may vary in forms and cannot be simplified to one particular type. Penman seems to generalize plain English as one type because she thinks the guidelines are the rules. ${ }^{19}$ Once again, they are not. The variety of plain English guidelines, however, does not signify the vagueness. Indeed, it shows the flexibility and the richness of approaches used by the movement.

Even though the plainness criteria are widely varied, the movement pays a great deal of attention to the readers' mind. To reach the readers' mind, the movement believes that the medium, that is the language, must be driven by the way with which it can be grasped rapidly into the mind. That, as shown by many linguistic research studies, can be created by using familiar vocabularies and putting limited words in one sentence. ${ }^{20}$ This is because first, lay persons have no adequate information about technical terms or jargon in law; and second our memory has limited capacity to collect a lot of information in a certain time..$^{21}$

Realizing those problems, however, the movement underlines the importance of writing in the simplest and clearest way. This is what Penman calls a commonality among the movement proponents. ${ }^{22}$ The problem with Penman in this context is that she stagnates her meaning about plain English to that concept: simplicity and clarity only. She narrows plain English as a movement that exaggerates and glorifies using less words and clear writing only. ${ }^{23}$ Her

\footnotetext{
${ }^{15}$ Ibid.

${ }^{16}$ Oxford Ginny dictionary, software in computer.

${ }^{17}$ David Mellinkoff, Mellinkoff's Dictionary of American Legal Usage, (St. Paul, MN: West Publishing Co., 1992), in C. Mowat supra note 11 (1999), p.4.

18J.C.Redish and S. Rosen, Can Guidelines Help Writers?, in E.R. Steinberg (ed), Plain Language Principles and Practice, (Detroit: Wayne State University Press, 1991), pp. 83-5.

${ }^{19}$ Although most of the proponents create the guideline and use it as guidance only, there is one article written by one of the proponents which call the guideline as a rule. See Judge Mark P. Painter, 30 Suggestions to Improve Readability or How to Write for Judges Not Like Judges, Legal Writing 201.

${ }^{20} \mathrm{An}$ average word in one sentence which plain English guidelines suggest is about 20-25 words. For example see J. Kimble, The Elements of Plain English, Michigan Bar Journal, October 2002.

${ }^{21}$ The theory was established by George Gopen. According to him, readers have a limited amount of energy on a passage of writing. This notion is quoted from Brian Hunt, Plain English in Legislative Drafting: Is It Really the Answer? 23 Statute Law Review 24, May 2002. See also V.R. Charrow, M.K. Erhardt, R.P. Charrow, Clear and Effective Legal Writing, (New York: Aspen Publisher, INC., $3^{\text {rd }}$ edition, 2001), p. 157.

22R. Penman (1992), p. 3.

${ }^{23}$ R. Penman (1992), p.4.
} 
assumption, however, hides the implication that there is no precision in plain English.

Reducing words and clarity, indeed, are the important matter in plain English. But they are not enough. Another crucial aspect that must be conveyed by plain English, as all legal documents require, is the precision. The difference between plain English and traditional legal language in reaching the precision, however, is in the way they convey the word to reach the precision. The traditional style prefers to put a lot of words and use long sentences to get the precision. In other words, it uses verbose words and long sentence. At the worst it is full of repetition. Plain English believes that the precision still can be obtained by using minimum words, using straightforward words.

Take this article as an example. This was a regulation in the United States which was drafted in the traditional style. It stated that:

“No person shall prune, cut, carry away, pull up, dig, fell, bore, chop, saw, chip, pick, move, sever, climb, molest, take, break, deface, destroy, set fire to, burn, scorch, carve, paint, mark, or in any manner interfere with, tamper, mutilate, misuse, disturb or damage any tree, shrub, plant, grass, flower, or part thereof, nor shall any person permit any chemical, whether solid, fluid, or gaseous, to seep, drip, drain, or be emptied, sprayed, dusted or injected upon, about or into any tree, shrub, plant, grass, flower, or part thereof, except when especially authorized by competent authority; nor shall any person build any fire, or station or use any tar kettle, heater, road roller or other engine within an area covered by this part in such a manner that vapor, fumes, or heat therefrom may injure any tree or other vegetation."

This regulation contains 141 words. At the first glance, it is almost hard to expect readers can grasp the meaning immediately. But this regulation can be possibly redrafted like this: "Do not damage the vegetation". ${ }^{24}$ These five alternative words still can be precise and indeed it is very helpful in order to make the regulation more readable without losing any essential part of it. This proves that plain English pays a serious attention to, and also strives for, the precision as well as the clarity and simple words.

In conclusion, Penman's assumption about plain English in this part is hard to accept. Plain English is not a word of art. Nor does it mean only a clear and simple writing. Its meaning in fact also includes a precise writing.

${ }^{24}$ Edwin Tanner, Plain English and Commercial Drafting, Lecture, 1, Victoria University, 2006, p. 13. 


\section{Plain English is text-based minded}

Analyzing Hathaway (1983), Kelly (1989), and Cutts (1993), Penman concludes that plain English equates with language and word style or with matters of texts. ${ }^{25}$ She added in the last part of her writing; "...the very labels 'plain English' or 'plain language' can be misleading. These labels focus on the writer and the words, and can often occlude the reader from view." 26 Using Coe's distinction, Penman underlines that plain English is trapped in the text-based approach which merely focuses on the document, not the reader per $s e .{ }^{27}$

In one sense, Penman is true. Most plain English guidelines deal with word matters. In fact, the main focus of plain English is language itself. This is because of traditional legal language, namely legalese.

Legalese has overwhelmed legal documents for centuries. ${ }^{28}$ It is larded with law-Latin English. It is also mysterious in form and expression, dependent on the past and archaic. ${ }^{29}$ Additionally, Butt described the feature of legalese as a language undesirably oozing with illogical order, complex grammatical structure, sentences of excruciating length, verbosity, and undue technicality. ${ }^{30}$ Furthermore, it uses jargon, archaic and obsolete words. ${ }^{31}$

People who engage in plain English believe that there is no persistent need anymore to retain legalese, ${ }^{32}$ since it absolutely failed to communicate to lay persons who are the first audience of laws. This is because legalese, as can be recognized from its features above, tends to be long sentences, intricate, superfluous, full of embellishment, and convoluted. Moreover, its vocabulary fits only lawyers or those who have a legal background. Despite helping people to understand legal documents, writing in legalese blocks communication between laws and their intended object.

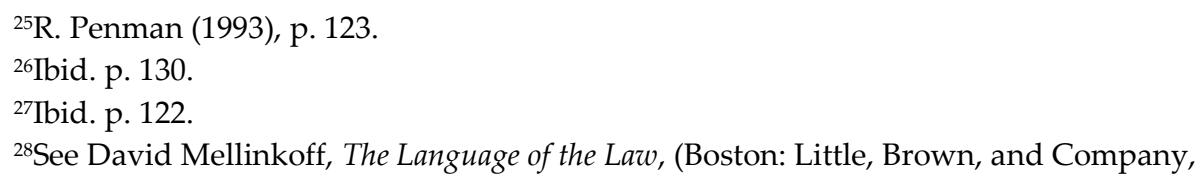

${ }^{30} \mathrm{P}$. Butt, Plain Language in Property Law: Uses and Abuses, 73 Australian Law Journal (November, 1999), p. 808.

${ }^{31} \mathrm{~J}$ K Aitken and P. Butt, The Elements of Drafting, (NSW: Thomson Lawbook, $10^{\text {th }}$ edition, 2004), p. 3-4.

${ }^{32}$ For example, R.W. Benson wrote an article with a bombastic title 'The End of Legalese: The Game is Over', 8 New York University Review of Law and Social Change 3, (1984-1985). All plain English guidelines avoid legalese. 
To illustrate the worse impact of legalese, Will Roger (1879-1935) blatantly said: "The minute you read something and you cannot understand it, you can be sure it was written by a lawyer" (written in legalese). ${ }^{33}$

Legalese no doubt has made a distance between the reader and the text. Using legalese will draw fogginess around the words and make them unintelligible. There have been uncountable cases standing before the courts because of the lack of understanding of words in legal documents. Not only money has been spent in these disputes finding the exact meaning of legal words before the courts, but also uncountable time has been wasted in dealing with legalese. The plain English movement with its credo 'clear, simple, and precise' tries to reduce those problems. ${ }^{34}$

The immense attention to dealing with legalese in the plain English movement actually is inevitable. Most of the problems of understanding legal documents occur because of it. To solve and reduce the problem, of course, plain English proponents have to deal with the linguistic problem: the problem of words. In this instance, what Penman sees, that plain English seems to be a textbased approach could not be denied.

The text-based approach is the first and indeed a necessary way of what those who engage in the movement intend to do. To make lay persons with mediocre knowledge understand laws and make laws can communicate clearly to their intended audience, the first thing that wordsmiths have to do is to rid of linguistic problems. Ridding of linguistic hurdles created by legalese, of course, is a matter of text approach.

However, positioning the movement as merely document-based minded undoubtedly neglects the long history of it. The rapid increasing demands of plain English documents have been accelerated by consumers' movements around the world. The plain English movement has grown to satisfy consumers: the readers. From here, it can be inferred that from the beginning plain English has existed to readers and problems with legalese are the readers' problem not lawyers.

From this point of view, however, it can be assumed that the movement totally focuses on the reader. Text approach actually is only a tool to deal with how to satisfy the reader. The separated notion between text-based approach and reader-based approach therefore is not relevant to analyze the plain English movement.

${ }^{33}$ Cited from M. M Asprey (1999), p. 29. The bold words come from the writer not originally from Roger.

${ }^{34}$ Almost all plain English guidelines reveal those advantages. See for example, Kimble (1997), Butt and Castle (2001), and B. Eunson, Writing in plain English, (Queensland: John Wiley \& Sons, 1996), p.5. 
Thus, both of them do not exclusively nullify each other. Furthermore the plain English movement should not be identified with one approach as against another. ${ }^{35}$ Labeling plain English as text-based approach writing, as Kimble adds, is not listening to the full choir of the movement. Therefore, it is unhistorical to say so. Moreover, in a real and practical ground, both approaches are used inherently and inextricably in plain English writing.

\section{No empirical evidence supported plain English}

Continuing her inefficacy of plain English, Penman denies the success story of the plain English movement. For her, evidence provided by the supporters is insufficient, hence fails to attract necessary support for them. ${ }^{36}$ Moreover, she proposed counter evidence to prove the failure of claims made by the movement. ${ }^{37}$

She reviles evidence proposed by the movement deemed as inadmissible because it was obtained from limited respondents, ${ }^{38}$ using simple approaches ${ }^{39}$ and did not follow research literature..$^{40}$ Unfortunately, the same reason could be addressed to her to reject her counter evidence. Her study in testing insurance documents, for example, was followed by only 18 participants. This is, though, a small number to infer a general conclusion about one particular hypothesis. Thus, I assume those people were neither random nor representative samples. Even to some extent she asserts that she had used a complicated approach, the two previous arguments are enough to reject her research finding.

There is long-standing and certainly very large amount, evidence proving that plain English movement has somehow contributed in increasing people's understanding of legal documents. Kimble, for example, has listed and also conducted many studies that show the capability of plain English guidelines to improve comprehension in reading legal documents. ${ }^{41}$ Many other proponents have also tested the work of plain English guidelines in real life. Martin Cutt, ${ }^{42}$ David S.T. Kelly, ${ }^{43}$ Robert Benson, ${ }^{44}$ Harvey S. Perlman, ${ }^{45}$ and Edwin Tanner, ${ }^{46}$ to

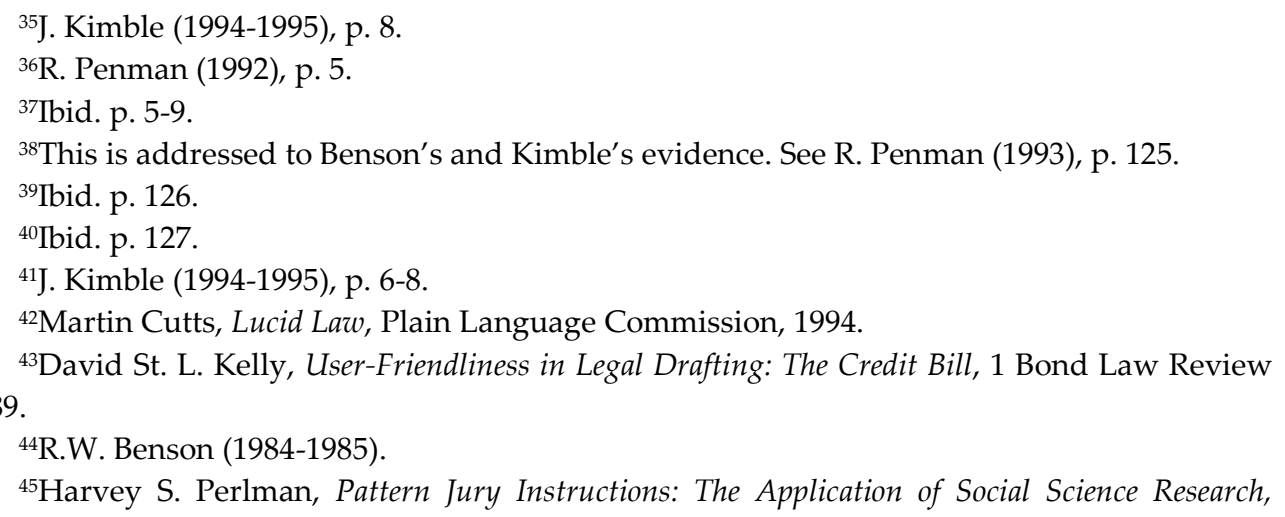

${ }^{45}$ Harvey S. Perlman, Pattern Jury Instructions: The Application of Social Science Research, Nebrasca Law Review Vol. 65, 1986. 
name a few, conducted such studies. All studies happily have supported the movement assumption; readers or clients prefer plain English. ${ }^{47}$ It is because they can access legal documents readily and directly without any serious help from professionals.

However, maybe Penman is still dissatisfied with all evidence. She might argue that those facts are not valid and readable enough because of some reasons she has imagined. That is fine. But how can she explain governments' endorsement to the movement around the world like in USA, Australia, Europe Union, or Canada? Does she think that policy makers in those countries just play and spoil some people to get their support? I do not think the governments dare issuing, for example, an executive order to encourage the movement without any reserves and, of course, reasonable arguments. As politicians, it is too risky to make one particular decision without considering its political impact such as public trust or opinion and parliament's support. I believe persons like President Carter for example had thought and discussed seriously with his colleagues when he issued an executive order to make regulations as simple and clear as could be. ${ }^{48}$

The main reason to see why those governments supported the movement is the public interest. It means that members of public are widely eager to be taken into account in the law making process. The endorsement in this context could be meant as an answer to public demands in the call for simple and clear language in legal documents. The demands inevitably are strong evidence to show how plain English becomes an undeniable factor in helping people, and perhaps also politicians, to read laws and get public attraction respectively.

Although plain English scientifically and psyco-socially has bridged between laws and their proposed audiences, the result, however, will never reach a perfect point. The increased performance in readers' comprehensibility is about 20-60 \% on average. A study carried out by Cutts for instance showed that respondent's understanding of Timeshare Act 1993 (UK) improved only by 46 $\% .{ }^{49}$ Therefore, there is no $100 \%$ improvement. Plain English proponents admit that. Yet, there are limitations in plain English.

The limitations come from at least two sources. First, the degree of intelligibility. Generally speaking, every person has different knowledge and capacity. Educational background and brain capacity develop our knowledge and capacity. Writing, reading and then understanding processes require some

\footnotetext{
${ }^{46}$ Edwin Tanner, The Comprehensibility of Legal Language: Is Plain Language the Solution?, 1 Monash University Law Review 52, 2000.

${ }^{47}$ P. Butts (2002), p. 15.

${ }^{48}$ US Executive Order 12044 (23 March 1978) and US Executive Order 12174 (30 November 1979). See Asprey (1999), footnote no. 31 and 32, p. 34.

${ }^{49}$ Martin Cutts (1994).
} 
intellectual capacity. There are intellectual exercises which vary in their performance, result, or achievement. Three drafters, for example, will redraft one article in an act in different ways because they have different knowledge, capacity and experience. The same figure will appear in readers' side during reading process.

Second, regarding legal documents there is a lack of legal knowledge between lawyers and their clients, or in the case of public documents between drafters and members of public. James $B$. White says that there is the 'invisible discourse' of laws which non-lawyers will not familiar with it. ${ }^{50}$ This 'invisible discourse' impedes communication between the parties.

Lawyers are constructing their assumed knowledge when they are drafting documents. This prior knowledge has been developed and inherited among them, both formally (via schools for instance) and informally (in their milieus like in courts). Some legal vocabularies with technical meanings, theories, principles, rules, standards, or interpretations have overwhelmed lawyers' world. Those have driven lawyers when they are dealing with clients or writing legal documents.

Therefore, the simplest language in legal documents still contains legal concepts which non-lawyers might not grasp. Legal documents, however, are laws. They cannot be treated as ordinary papers. They are full of "legal schemata". ${ }^{51}$

Unfortunately, plain English cannot wipe those limitations away. Even the plainest English in legal documents cannot guarantee that lay persons can grasp them in the best level of comprehension and readability. However, among other things, plain English movement contributes much in making lay people easily understand legal documents as it is proved by many studies.

\section{Certain meaning (?)}

The last argument of Penman's critics is related to the belief of the universality or uniformity of words' meaning. She said that plain English argument treats language 'as if it were a system or code' ${ }^{52}$ In other words, she pointed out that plain English was driven by a desire to force one particular way in terms of communication activity. Continuing her argument, she believes that there is no certainty in generating meaning from words; there is no a universal or uniformed concept about what one word means. Readers (or hearers), as a

${ }^{50}$ James Boyd White, Heracles' Bow: Essays on the Rhetoric and Poetic of the Law, Wisconsin: University of Winconsin Press, 1985 in Edwin Tanner, Plain English and Commercial Drafting, Lecture 6, Victoria University, 2006.

${ }^{51}$ Ibid.

${ }^{52}$ R. Penman (1992), p. 16. 
consequence, could create meaning in different ways from what writers (or speakers) intend to.

On one hand, Penman's notion is parallel with what postmodernism believes. Postmodernism refuses the concept of universality and certainty to explain reality. For its proponents the reality comes into being through interpretation made by individuals. Every one has their own assumption, understanding, and also meaning about the reality which is relative and fallible to others..$^{53}$ Therefore, there is no an absolute interpretation. Hence, there is no certainty.

On the other hand, she stands on the constructionist model of communication. Similarly, to the postmodernism, the constructionist asserts that a meaning is resided exclusively, or almost entirely, with the reader. ${ }^{54}$ The text is freely to be interpreted by the reader. The text internalizes in reader's world view and uproots from the intended meaning of its creator. As a consequence, every reader will have their own meaning even from the same text. There are no the same meaning even from the same person if he or she reads different text. In this way, contexts, knowledge, and skills play an important role in generating meaning. ${ }^{55}$

Having this constructionist model will make us rejecting the existence of language consensus in dictionaries or denying any technical terms in particular field of studies. Moreover, applying this particular approach to legal documents will make law impossible to enforce. There will be no order and harmony because people can interpret statutes or other legal documents as they will. As a result, there will be a social anarchy.

Considering the function of law as a means to uphold justice among people, certainty, therefore, is a nonnegotiable precondition. If there is no certainty, how can be an order or a harmony in society, and in practical application how can the judge make a verdict to reveal a justice. Therefore, determined meaning must be attained. This would happen if there is a collaborative understanding of the text.

The meaning must be generated from both side the writer and the reader. Communication between them is of the vital and fundamental in order to settle the meaning, even in indirect way by seeking writer's background for instance. This is what the interactive model argues in communication theory. ${ }^{56}$ In legal discourse, the model was shown by H.L.A. Hart when he explains his theory

\footnotetext{
${ }^{53}$ Postmodernism, http://www.pbs.org/faithandreason/gengloss/postm-body.html (30 September 2006).

${ }^{54}$ Edwin Tanner, Plain English and Commercial Drafting, Lecture, 2, Victoria University, 2006, p. 23.

${ }^{55}$ Ibid.

${ }^{56}$ Ibid.
} 
about the core and the penumbra. In his theory, he illustrates that communication occurs when there is a conventional meaning (the core) even it may be encircled by an uncertain meaning, a penumbra. ${ }^{57}$

The convention bears an agreement. The agreement then produces a certainty. The certainty appears because people can control the meaning of words they use. Only in this circumstance, justice can be achieved and law can be performed because law requires an objective meaning. Additionally, it performs to convey an exact meaning about reality. Law to some extent dictates the reality. For this purpose, courts hold the case.

Believing the postmodernism and the constructionist idea, therefore, is totally out of legal system. Penman's notion in this context, as a result, is not relevant. Although her notion curiously is very interesting because she invites the movement get involved in communication debate, it does attack the core of the legal axiom. Beside that, it will deconstruct social order and systems which have established for centuries such as courts' system, parliamentary system, etc.

From this point of view, it can be argued that it is true that plain English stands on a system or code; that is legal system which obtains certainty. However, the certainty in plain English communication is obtained interactively. Drafters as much as they can must deliberately communicate the meaning of the text in legal documents to the reader. Implementing this condition, therefore, plain English reduces as much as it can to use technical words. ${ }^{58}$

\section{Conclusion}

Penman's criticisms are worth to get serious attention. They are not a straw man as Reddish sees. The criticisms deserve to get responses. Indeed, by critics the movement can develop a stronger and better intellectual basis to attract people getting involved. Penman, like other person who questions the movement's claims, ${ }^{59}$ has contributed to the movement in the way she always challenges the exponents to convince traditional lawyers who still perpetuate legalese.

She might correct when she says that plain English cannot make lay people entirely having the best comprehensive understanding of legal documents. The movement honestly admits that. Plain English, however, is only a part solution ${ }^{60}$ to make legal documents more understandable to lay people. But it means something, not anything as she believes.

\footnotetext{
${ }^{57}$ Ibid. p. 26.

${ }^{58}$ Aitken \& Butts (2004), p. 18. See also J. Kimble (2002).

${ }^{59}$ For instance Brian Hunt (2002).

${ }^{60}$ Edwin Tanner, E. (2000).
} 


\section{Bibliography:}

Aitken, J.K. and Butt, P. (2004), The Elements of Drafting, (NSW: Thomson Lawbook, $10^{\text {th }}$ edition)

Asprey, M.M. (1999), Plain Language for Lawyers, (NSW: the Federation Press, $2^{\text {nd }}$ edition).

Benson, R.W. (1984-1985), The End of Legalese: The Game is Over', 8 New York University Review of Law and Social Change 3.

Butts, P. (1999), Plain Language in Property Law: Uses and Abuses, 73 Australian Law Journal.

----- and Castle, R. (2001), Modern Legal Drafting A Guide To Using Clearer Language, (Victoria: Cambridge University Press).

---- (2002), The Assumptions Behind Plain Legal Language, paper presented in the Fourth Biennial Conference of PLAIN Language Association International, Canada: September, 27. Available in http://www.plainlanguagenetwork.org/conferences/2002/assumptn/assu mptn.pdf (27 September 2006).

Charrow, V.R., et.al. (2001), Clear and Effective Legal Writing, (New York: Aspen Publisher, INC., $3^{\text {rd }}$ edition).

Cutts, M. (1994), Lucid Law, Plain Language Commission.

Eunson, B. (1996), Writing in Plain English, (Queensland: John Wiley \& Sons)

Hunt, B. (2002), Plain English in Legislative Drafting: Is It Really the Answer?, 23 Statute Law Review 24.

Kelly, D. S. L.(1989), User-Friendliness in Legal Drafting: The Credit Bill, 1 Bond Law Review 143.

Kimble, J. (1992), Plain English: A Charter for Clear Writing, 9 Thomas M. Cooley Law Review 1.

----- (1994-1995), Answering the Critics of Plain language, 5 Scribes Journal Legal Writing 51.

----- (1996-1997), Writing for Dollars, Writing to Please, 6 The Subscribe Journal of Legal Writing 1.

---- (1998-2000)., The Great Myth That Plain Language Is Not Precise, 7 The Subscribe Journal of Legal Writing 109.

----- (2002), The Elements of Plain English, Michigan Bar Journal.

Law Reform Commission of Victoria (1987), Plain English and the Law, Report No. 9. 
Mazur, B. (2000), Revisiting Plain Language, 47 Technical Communication, the Journal of the Society for Technical Communication 2.

Mellinkoff, D. (1963), The Language of the Law, (Boston: Little, Brown, and Company).

Mowat, C. (1999), A Plain Language Handbook for Legal Writers, (Toronto: Carswell)

Painter,M.P.J., 30 Suggestions to Improve Readability or How to Write for Judges Not Like Judges, Legal Writing 201.

Penman, R. (1992), Plain English; Wrong Solution to an Important Problem, 19 Australia Journal of Communication 3.

---- (1993), Unspeakable Acts and Other Deeds: A Critique of Plain Legal Language, 7/2 Information Design Journal 12.

Perlman, H.S. (1986), Pattern Jury Instructions: The Application of Social Science Research, Nebrasca Law Review Vol. 65.

Postmodernism, http://www.pbs.org/faithandreason/gengloss/postm-body.html (30 September 2006)

Steinberg, E.R.(ed) (1991), Plain Language Principles and Practice, (Detroit: Wayne State University Press).

Tanner, E. (2006), Plain English and Commercial Drafting, Lecture 1, 5, 6, Victoria University.

Tanner, E. (2000), The Comprehensibility of Legal Language: Is Plain Language the Solution?, 1 Monash University Law Review 52. 